\title{
Allosteric Activation of Yeast Enzyme Neutral Trehalase by Calcium and 14-3-3 Protein
}

\author{
M. ALBLOVA ${ }^{1}$, A. SMIDOVA ${ }^{1}$, D. KALABOVA ${ }^{1}$, D. LENTINI SANTO ${ }^{2}$, T. OBSIL ${ }^{1,2}$, \\ V. OBSILOVA ${ }^{1}$
}

${ }^{1}$ Department of Structural Biology of Signaling Proteins, Division BIOCEV, Institute of Physiology of the Czech Academy of Sciences, Vestec, Czech Republic, ${ }^{2}$ Department of Physical and Macromolecular Chemistry, Faculty of Science, Charles University, Prague, Czech Republic

Received May 30, 2018

Accepted October 3, 2018

Epub Ahead of Print January 10, 2019

\begin{abstract}
Summary
Neutral trehalase 1 (Nth1) from Saccharomyces cerevisiae catalyzes disaccharide trehalose hydrolysis and helps yeast to survive adverse conditions, such as heat shock, starvation or oxidative stress. 14-3-3 proteins, master regulators of hundreds of partner proteins, participate in many key cellular processes. Nth1 is activated by phosphorylation followed by 14-3-3 protein $(\mathrm{Bmh})$ binding. The activation mechanism is also potentiated by $\mathrm{Ca}^{2+}$ binding within the EF-hand-like motif. This review summarizes the current knowledge about trehalases and the molecular and structural basis of Nth1 activation. The crystal structure of fully active Nth1 bound to 14-3-3 protein provided the first high-resolution view of a trehalase from a eukaryotic organism and showed 14-3-3 proteins as structural modulators and allosteric effectors of multi-domain binding partners.
\end{abstract}

\section{Key words}

14-3-3 protein • Trehalase • Calcium • Trehalose • Allostery • Conformation $\bullet$ Enzyme $\bullet$ Crystal structure

\section{Corresponding author}

M. Alblova and V. Obsilova, Department of Structural Biology of Signaling Proteins, Division BIOCEV, Institute of Physiology of the Czech Academy of Sciences, Prumyslova 595, 25250 Vestec, Czech Republic. E-mail: miroslava.alblova@fgu.cas.cz or veronika.obsilova@fgu.cas.cz

\section{Introduction}

Trehalose ( $\alpha$-D-glukopyranosyl- $\alpha$-D-glukopyranoside) is a non-reducing disaccharide first discovered in ergot of rye in 1832. Trehalose has been known as trehalose since 1858 when Marcellin Berthelot isolated this disaccharide as sweet trehala manna from weevil cocoons (reviewed in Elbein 1974, Nwaka and Holzer 1998). In the following decades, trehalose was discovered also in the yeast S. cerevisiae (Koch and Koch 1925) and in bacteria, plants, fungi, insects and other invertebrates but never in mammals (Elbein 1974, Thevelein 1984b, Nwaka and Holzer 1998). Because no trehalose synthesis has been shown in vertebrates, the trehalose pathway can be a target for the development of drugs against pathological fungi (Van Dijck et al. 2002, Foster et al. 2003, Petzold et al. 2006). The production of trehalose is induced by adverse living conditions, such as drought, extremely low or high temperatures, oxidative stress or toxic chemicals (Nwaka et al. 1995, Zahringer et al. 1997).

Trehalose can be synthetized from UDP-glucose and glucose-6-phosphate using two-step catalysis by a complex of trehalose-6-phosphate synthase (TPS1) and trehalose-6-phosphate phosphatase (TPS2) (Vandercammen et al. 1989, Londesborough and Varimo 1984). Trehalose accumulation protects cell membranes and proteins against damage, and trehalose can also act as a signaling molecule connecting its metabolism with glucose transport and with glycolysis (reviewed in Wiemken 1990).

In some bacterial species, trehalose was identified as a part of cell walls, especially in 
aktinomycetes (reviewed in Elbein et al. 2003). Cell trehalose levels depend on the cell cycle phase, nutrition and living environment. The content of trehalose is crucial for fungi spore germination (Rousseau et al. 1972, Thevelein 1984b). Moreover, trehalose is the main compound of the insect haemolymph and is crucial for insect flight. Thus, trehalase, the enzyme responsible for trehalose hydrolysis, is frequently used as a target for the development of new insecticides (Becker et al. 1996, Gibson et al. 2007). Trehalose accumulation is also a common feature of many anhydrobiotic organisms, which can survive decades without water (Crowe $e t$ al. 1984, Crowe et al. 1992).

Yeast with low trehalose concentrations are more sensitive to draught and heat damage, whereas yeast with high trehalose levels are more likely to survive (Hottiger et al. 1987). In the yeast S. cerevisiae trehalose is one from the main storage saccharides and form from $1 \%$ to more than $23 \%$ dry cell mass, depending on the living conditions and the cell cycle phase (Lillie and Pringle 1980). Many studies have confirmed the connection between trehalose accumulation in yeast cells and their tolerance to temperature extremes, dehydration or cyclic freezing and melting. These studies in yeast suggested that trehalose functions not only as carbohydrate storage or energy reserve but also as a membrane and protein protector during low levels of intracellular water (reviewed in Wiemken 1990, Nwaka and Holzer 1998). The ability of trehalose to protect proteins against denaturation and to protect other cellular components in vitro correlates with the protective function against various environmental stresses in vivo (De Virgilio et al. 1994, Hottiger et al. 1994).

Trehalase, the enzyme hydrolyzing trehalose, was first discovered in Aspergillus niger, in 1893, and Hermann Emil Fischer described a similar enzyme in S. cerevisiae two years later (Fischer 1895). Trehalases ( $\alpha, \alpha$-trehalose-1-C-glukohydrolases) are part of the Glycoside hydrolase family 37 (EC 3.2.1.28) of O-Glycosyl hydrolases (EC 3.2.1.) which includes enzymes with mutual trehalase activity identified in many different organisms, from bacteria to fungi, plants and animals (Elbein 1974, App and Holzer 1989, Kopp et al. 1993). Trehalases are conserved enzymes that catalyze the hydrolysis of one of two glycoside bonds of trehalose (Kopp et al. 1993, Kopp et al. 1994, Nwaka and Holzer 1998, Bock et al. 1983). In the yeast S. cerevisiae, trehalose can be hydrolyzed by the neutral trehalases Nth1 and Nth2, which share $73 \%$ identity, and by the acid trehalase Ath1 (Thevelein 1984a, Thevelein 1984b, Nwaka et al. 1995). Nth1 and Nth2 are located in the cytosol, whereas Ath1 is present in vacuoles. The $\mathrm{pH}$ optimum of phosphorylated Nth1 (pNth1) is 7.0, in contrast to Ath1 with a pH optimum 4.5 (Londesborough and Varimo 1984, Wiemken 1990, App and Holzer 1989). The molecular weight of Nth1 is $86 \mathrm{kDa}$, and this enzyme shows strict specificity for trehalose with no evidence of hydrolysis of other tested disaccharides, such as cellobiose, maltose, lactose, sucrose, raffinose or melibiose (App and Holzer 1989, Gibson et al. 2007).

Nth1 regulation of trehalose plays a key role in yeast metabolism and in the activities of important enzymes, including hexokinase (Nwaka and Holzer 1998). Disruption of the vegetative rest of yeast and fungi spores by heat shock or glucose addition sharply increases trehalase activity (Van Assche et al. 1972, Thevelein et al. 1982, van der Plaat 1974). Nth1 activation by glucose is a reversible process (Thevelein and Jones 1983). After heat shock, Nth1 expression increases with trehalose synthase expression and with trehalose concentration (Nwaka et al. 1995, Nwaka et al. 1996). These seemingly useless cyclic trehalose conversions during heat shock are likely necessary for maintaining the cytosolic glucose concentrations constant, which is essential for heat shock survival (Hottiger et al. 1987, Nwaka et al. 1995, Nwaka et al. 1996). Moreover, trehalose maintains proteins and membranes in their native state under high temperatures and decreases protein aggregation. However, the complete trehalose degradation is required for recovery after heat shock (Singer and Lindquist 1998). Nth1 expression is also induced by chemical stresses, such as $\mathrm{CuSO}_{4}$ and $\mathrm{NaAsO}_{2}$ (toxic chemicals), $\mathrm{H}_{2} \mathrm{O}_{2}$ (oxidative stress) or cycloheximide (proteosynthesis inhibition), thus suggesting that Nth1 participates in defense mechanism against oxidative stress or toxins. Conversely, osmotic stress-induced processes cause no changes in trehalose concentrations (Zahringer et al. 1997).

The yeast Nth1 has a unique N-terminal extension, in comparison with other trehalases from different organisms (Nwaka and Holzer 1998, Veisova et al. 2012), which can be phosphorylated by cAMPdependent proteinkinase (PKA) or by cyclin dependent kinase 1 (Cdk1) (Uno et al. 1983, Ortiz et al. 1983, van der Plaat 1974, Panni et al. 2008, Veisova et al. 2012). Other structural domain features include a conserved catalytic domain (Nth1-CD, residues 180-751) and a $\mathrm{Ca}^{2+}$-binding domain (Nth1-CaBD, 
residues 96-176) with a so-called EF-hand-like motif (Fig. 1A). Nth1 can be activated by combination of $\mathrm{Ca}^{2+}$-binding (Franco et al. 2003, Kopecka et al. 2014) and phosphorylation (Ortiz et al. 1983, Uno et al. 1983) followed by 14-3-3 protein binding (Panni et al. 2008, Veisova et al. 2012). Moreover, studies show that Nth1 activation is closely related to yeast cell cycle progression and metabolism (Zhao et al. 2016, Ewald et al. 2016) (Fig. 1B).

The same activation mechanism can be also expected for Nth2 whose primary structure differs only in the additional 32 amino acids within the $\mathrm{N}$-terminal part but the PKA phosphorylation motifs and both $\mathrm{Ca}^{2+}$-binding and catalytic domains remain highly conserved. The function of Nth2 was partially revealed by the deletion of NTH2 gene in S. cerevisiae which did not influence the trehalose metabolism but increased the sensitivity to heat shock (Nwaka et al. 1995).

Trehalose and glycogen, the most important carbohydrate storages of yeast, are highly abundant in slow-growing cells and can serve as long-term carbon reserves. Moreover, they enable cell cycle progression during starvation (Ewald et al. 2016, Francois and Parrou 2001). Their levels are under strong cell cycle control, facilitated by a key cell cycle regulator, Cdk1, and by the metabolic regulator PKA (Guillou et al. 2004, Kuenzi and Fiechter 1969, Muller et al. 2003, Ewald et al. 2016,
Zhao et al. 2016). The relationship between PKA- and Cdk1-dependent Nth1 activation has not been studied yet, but studies have already shown that the regulatory subunit of PKA (Bcy1) is a substrate for Cdk1, and three G1 cyclins have multiple PKA sites. Moreover, PKA activity peaks at the Start of the cell cycle, when Cdk1 activity is also high. Thus, these two kinases may potentiate each other while regulating Nth1 (Muller et al. 2003, Zhao et al. 2016, Holt et al. 2009, Ubersax et al. 2003). At the G1/S transition, Cdk1 and PKA phosphorylate and activate Nth1 and glycogen phosphorylase (Gph1), thereby causing trehalose and glycogen breakdown, respectively. In the early G1 phase, in slow-growing cells, carbohydrate storage levels rise, whereas in the late G1 phase, when cells enter the cell cycle, both main storage sugars are broken down into glucose. During the $\mathrm{S} / \mathrm{G} 2 / \mathrm{M}$ phases, Nth1 releases trehalose to fuel biosynthesis (Fig. 1B). Thus, catabolism can be coordinated with cell cycle progression and final cell division (Kuenzi and Fiechter 1969, Sillje et al. 1999, Muller et al. 2003, Zhao et al. 2016). The constant concentration of Nth1 during the cell cycle confirms that its catalytic activity, rather than its abundance, is regulated by phosphorylation (Ewald et al. 2016).

Yeast $S$. cerevisiae has two 14-3-3 proteinencoding genes (BMH1 and $B M H 2)$, which are highly homologous and essential for most laboratory yeast
A

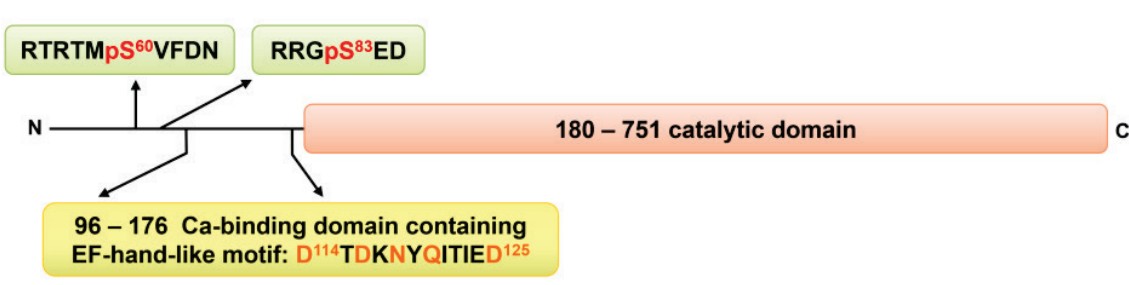

B

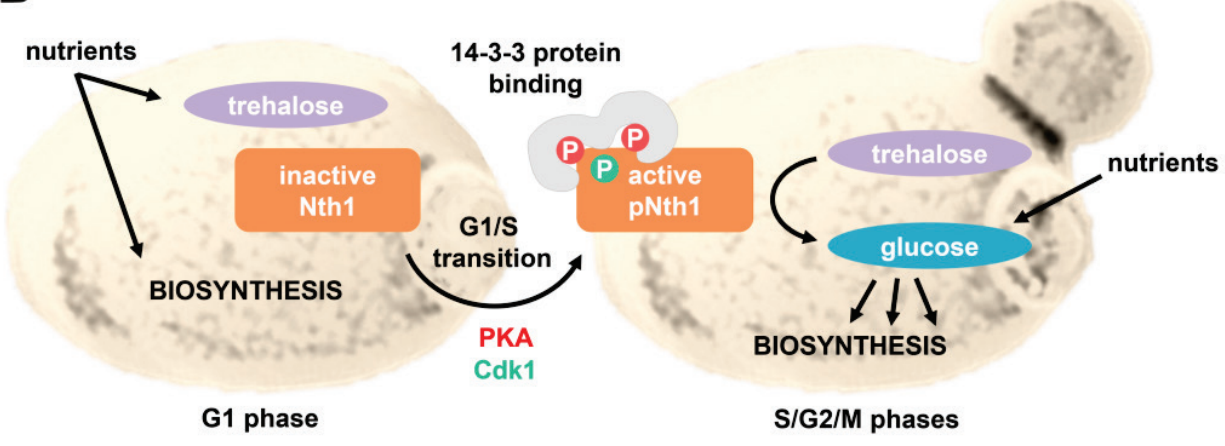

Fig. 1. Yeast neutral trehalase (Nth1) domain structure and function. (A) Domain structure of Nth1. The 14-3-3 binding motifs within the $\mathrm{N}$-terminal extension, the calcium-binding domain (Nth1-CaBD) and the catalytic domain (Nth1-CD) are shown in green and yellow and salmon, respectively. The positions of PKA phosphorylation sites crucial for 14-3-3 binding are in red. Residues involved in calcium ion coordination are shown in orange, indicated within the sequence of the EF-hand-like motif. (B) Nth1 phosphorylation and activation is closely linked to yeast metabolism and to cell cycle progression. Intracellular trehalose levels are under strong cell cycle control facilitated by the cell cycle regulator Cdk1 and by the metabolic regulator PKA. In the G1 phase the excess nutrients can be stored in a form of storage carbohydrates trehalose and glycogen which can be utilized in following $S, G 2$ and $M$ phases and used for biosynthesis. The stored trehalose cannot be hydrolyzed until the Nth1 is phosphorylated and activated at the G1/S transition. Yeast 14-3-3 protein (Bmh) binding is essential for full Nth1 activation and trehalose breakdown. During the S/G2/M phases, Nth1 hydrolyzes trehalose into two molecules of glucose for biosynthesis. Thus, catabolism can be coordinated with cell-cycle progression and final cell division (Alblova et al. 2017, Ewald et al. 2016, Veisova et al. 2012, Zhao et al. 2016). 
strains (van Heusden and Yde Steensma 2006, van Heusden 2009). Bmh proteins, originating from a conserved 14-3-3 protein family, interact with and affect the structure, localization, activity and thus the function of hundreds of different proteins. They play a key role in regulating several important cellular processes, such as metabolism, cell cycle, apoptosis and transcription or signal transduction (Aitken 1996, Fu et al. 2000). 14-3-3 proteins are expressed in all eukaryotic cells, their molecular weight is approximately $30 \mathrm{kDa}$, and they form rigid and highly stable homo- or heterodimers (Liu et al. 1995, Xiao et al. 1995). Each 14-3-3 protomer is formed by nine antiparallel $\alpha$-helices, and the rigid structure of 14-3-3 dimer has the typical cup-like shape with a large central channel containing two amphipathic ligand-binding grooves (Obsil and Obsilova 2011). Thanks to their rigidity, 14-3-3 proteins can function as scaffolding molecules or platforms for their binding partners (Yaffe 2002). In addition, the presence of two ligand binding grooves in the 14-3-3 protein dimer allows the simultaneous binding of two different ligands or the binding of one ligand using two phosphorylated motifs. This review summarizes the state of the art on Nth1 activation and regulation by phosphorylation followed by 14-3-3 protein and $\mathrm{Ca}^{2+}$ binding.

\section{Structural studies on trehalases}

The first high-resolution trehalase structure reported was the crystal structure of prokaryotic trehalase Tre37A from E. coli (Gibson et al. 2007). The structure of Tre37A consists of a $(\alpha / \alpha)_{6}$ barrel, which is a typical structural feature of other toroidal glycosylases such as glukoamylase (Aleshin et al. 1994), chitobiose phosphorylase (Hidaka et al. 2004) or maltose phosphorylase (Egloff et al. 2001). All these enzymes originate from the six-hairpin glycosidase superfamily, and they catalyze the anomeric inversion of substrate configuration. Recently, our group reported the crystal structure of the yeast Nth1 (Alblova et al. 2017). The active site of these two trehalases is located in a deep pocket, buried within the enzyme structure (Fig. 2) (Gibson et al. 2007, Alblova et al. 2017). Therefore, a significant conformational change may be necessary for the substrate/trehalose entry and product/glucose

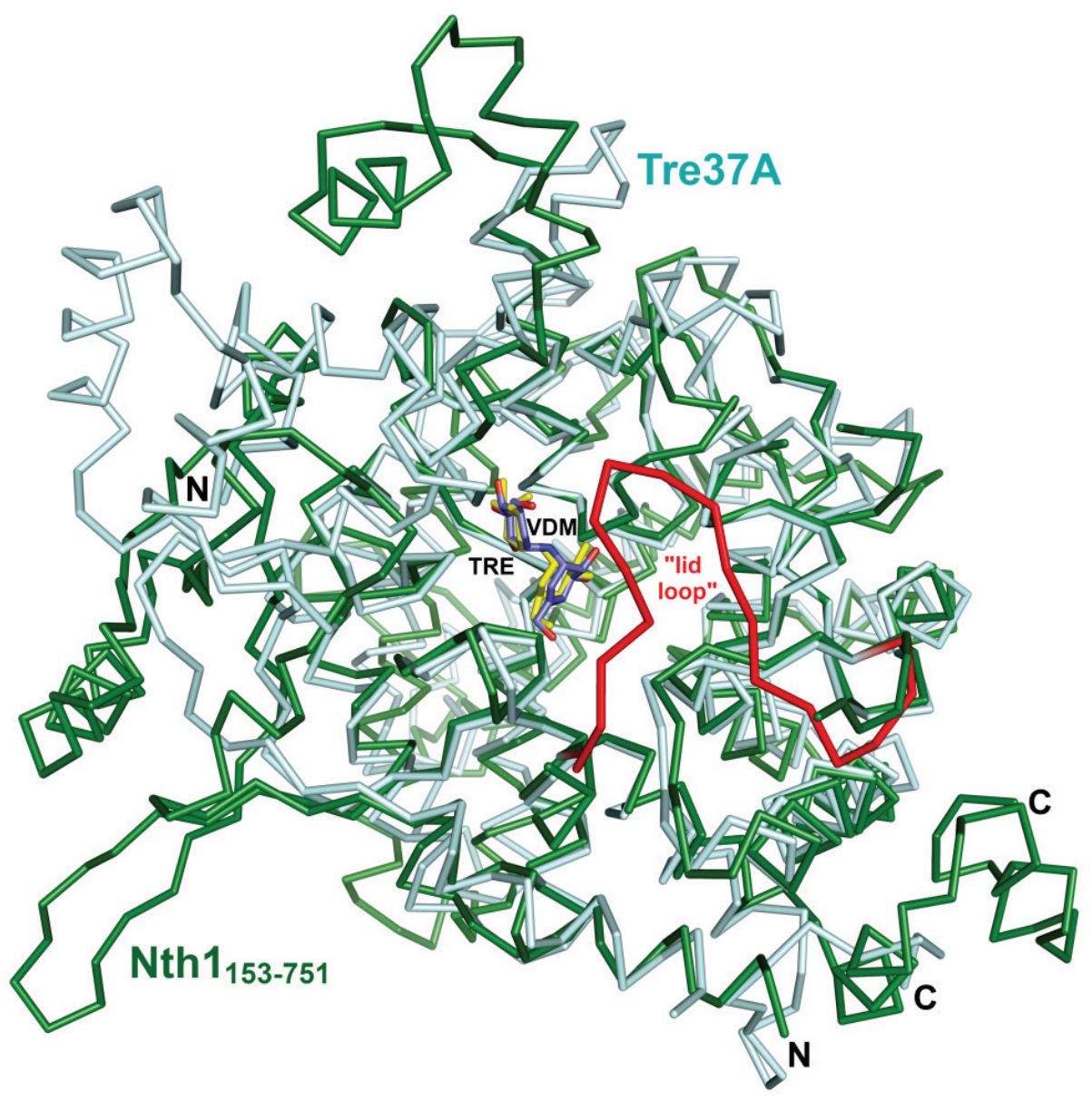

Fig. 2. Superimposition of the catalytic domains of yeast Nth $1_{153-751}$ (green, PDB: 5M4A) and periplasmic trehalase Tre37A from $E$. coli (cyan, PDB: 2JF4) (Alblova et al. 2017, Gibson et al. 2007). The Nth1-CD is shown in green, Tre37A is shown in light cyan and its "lid loop" in red. The active sites of Nth1 and Tre37A contain trehalose (TRE, in yellow) and validoxylamine $\mathrm{A}$ (VMD, in blue), respectively. 
departure. In E. coli Tre37A, glycosidic hydrolysis proceeds according to the canonical mechanism, which includes the nucleophilic attack of the substrate by water molecule. In this case, the residue D312 plays the role of a catalytic acid and the residue E496 of a Brønsted base during the hydrolytic reaction (Gibson et al. 2007). The structure of the catalytic domain of Nth1 $1_{153-751}$ bound to trehalose (TRE) shows similar features to those of the Tre37A structure bound to the inhibitor validoxylamine A (VDM) (Fig. 2 - green versus cyan). In comparison with Tre37A, Nth1 residues D478 and E674 act as catalytic acid and base, respectively, as confirmed by site-directed mutagenesis (Alblova et al. 2017). Furthermore, the superimposition of both trehalase structures revealed a key difference: in the Tre37A:VDM complex, the active site is completely covered by a loop containing polyglycine stretch (Tre37A sequence $\mathrm{S}^{501}$ TTGTGGGGGEYPLQDGF ${ }^{518}$, shown in red in Fig. 2). However, in the Nth1 $1_{153-751}$ :TRE complex, this loop is disordered, likely due to its high flexibility (Nth1 sequence $T^{679}$ RGTDPHRVEAEYGNQGADFKGAATE $\left.\mathrm{GF}^{706}\right)$. However, this loop region contains a pair of $\mathrm{EY}$ residues critical for catalysis conserved among all trehalases. Differences in the length, sequence and flexibility of these loop regions suggest that the regulation of yeast neutral trehalases substantially differ from that of prokaryotic trehalases.

\section{Regulation of yeast neutral trehalase}

In the yeast $S$. cerevisiae, Nth1 activity is regulated at both transcriptional and posttranslational levels. NTH1 expression is induced by different stress conditions, such as heat shock, chemicals or oxidative stress (Nwaka et al. 1995, Zahringer et al. 1997). Nth1 is regulated through phosphorylation by PKA, whose activity depends on cellular cAMP levels, and by Cdk1. The unique N-terminal extension of Nth1 contains four phosphorylation sites, namely Ser20, Ser21, Ser60 and Ser83, which are targets of PKA (Schepers et al. 2012, Panni et al. 2008, Veisova et al. 2012), and Ser66, which is phosphorylated by Cdk1 (Holt et al. 2009, Ewald et al. 2016, Zhao et al. 2016). The N-terminal extension is followed by a $\mathrm{Ca}^{2+}$ binding domain (Nth1-CaBD, residues 96-176) containing the EF-hand-like motif (sequence $\mathrm{D}^{114}$ TDKNYQITIED ${ }^{125}$ ) and the catalytic domain (Nth1-CD, residues 180-751), which is conserved among trehalases from different species
(Amaral et al. 1997) (Fig 1A). Sequence alignment of all trehalases available in UniProt showed that the $\mathrm{N}$-terminal extension and the $\mathrm{CaBD}$ are distinct features of fungi trehalases.

Biochemical and biophysical characterization of the interaction between yeast 14-3-3 proteins and PKA phosphorylated Nth1 (pNth1) revealed that both Bmh1 and Bmh2 isoforms form stable complexes with $\mathrm{pNth} 1$ with 2:1 molar stoichiometry (Bmh dimer binds one Nth1 molecule) and dramatically increase the catalytic activity of pNth1. Moreover, site-directed mutagenesis revealed that the phosphorylation sites Ser60 and Ser83 function as 14-3-3 binding motifs and are essential for pNth1 activation both in vitro and in vivo (Veisova et al. 2012).

The regulation of Nth1 activity by PKA phosphorrylation is a good example of reciprocal regulation of degradation and synthesis. During this process, trehalose6-phosphate synthase is inactivated by cAMP-dependent phosphorylation and reactivated by dephosphorylation (Panek et al. 1987). This is in line with trehalose degradation by Nth1 activated by cAMP-dependent phosphorylation and inactivated by dephosphorylation (Ortiz et al. 1983, App and Holzer 1989, Londesborough and Varimo 1984). Moreover, Dcs1, an mRNA decapping enzyme, inhibits 14-3-3 protein binding and acts as the negative regulator of trehalase activity. Thus, Dcs1 maintains Nth1 in the inactive form and prevents nonsense trehalose cyclic synthesis and degradation (Liu et al. 2002, De Mesquita et al. 2003, Schepers et al. 2012). Dcs1 deletion causes Nth1 activation but the deletion of both Bmh1 and Bmh2 proteins precludes Nth1 activation (Schepers et al. 2012).

$\mathrm{Ca}^{2+}$-dependent Nth1 activation requires $\mathrm{Ca}^{2+}$ binding to the EF-hand-like motif within the Nth1$\mathrm{CaBD} . \mathrm{Ca}^{2+}-\left(\right.$ or $\mathrm{Mn}^{2+}-$ ) dependent Nth1 activation can be inhibited by chelating agents such as EDTA or EGTA (Londesborough and Varimo 1984, App and Holzer 1989, Amaral et al. 1997, Franco et al. 2003). $\mathrm{Ca}^{2+}$-dependent Nth1 activation is much weaker than 14-3-3-dependent activation (Amaral et al. 1997, Franco et al. 2003, Veisova et al. 2012, Soto et al. 1999). However, the highest Nth1 activity was observed in the presence of both $\mathrm{Ca}^{2+}$ and 14-3-3 protein. The EF-handlike motif was first discovered in neutral trehalase from S. cerevisiae and K. lactis (Amaral et al. 1997) and subsequently in other yeast strains, such as $S$. pombe, Candida albicans, Aspergillus nidulans and Neurospora crassa (Soto et al. 1998, d'Enfert et al. 1999, Eck et al. 
1997). EF-hand-like motifs of neutral trehalases from different yeast strains contain aspartic acid residues at conserved positions 1, 3 and 12 and an asparagine residue at position 5 (Franco et al. 2003, Kopecka et al. 2014, Alblova et al. 2017). Mutational analysis of $S$. cerevisiae Nth1 revealed that the residues at positions 1, 5 and 12 of its EF-hand-like motif (D114, N118 and D125) are crucial for the $\mathrm{Ca}^{2+}$-dependent enhancement of the catalytic activity in the presence of 14-3-3 (Fig. 3) (Kopecka et al. 2014). Taken together, these results show that Nth1 is activated by phosphorylation followed by 14-3-3 protein binding and that the entire process is potentiated in the presence of $\mathrm{Ca}^{2+}$ (Franco et al. 2003).

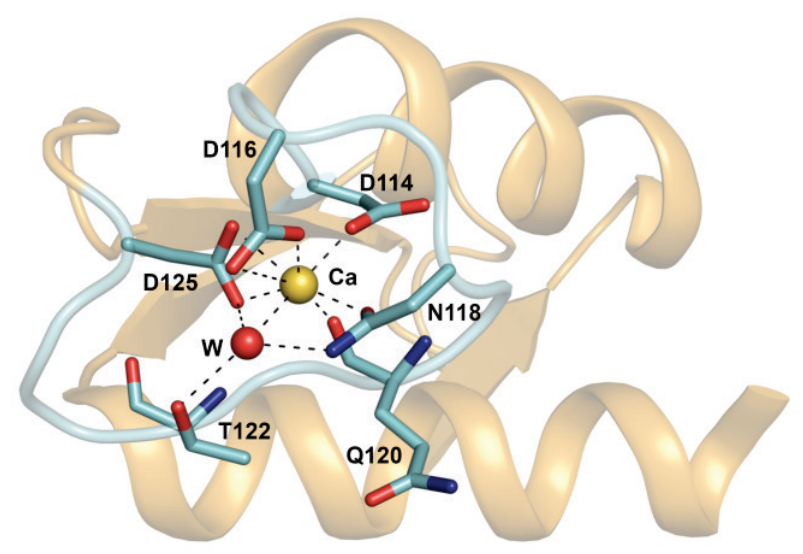

\begin{tabular}{|cccccccccccc}
\multicolumn{11}{c|}{ EF-hand-like motif of Nth1 } \\
\hline 1 & 2 & 3 & 4 & 5 & 6 & 7 & 8 & 9 & 10 & 11 & 12 \\
D $^{114}$ & T & D & K & N & Y & Q & I & T & I & E & D $^{125}$
\end{tabular}

Fig. 3. Close-up view of Nth1-CaBD containing EF-hand-like motif (shown in blue) and residues crucial for $\mathrm{Ca}^{2+}$ coordination. The $\mathrm{Ca}^{2+}$ ion and the water molecule (W) are shown in yellow and red, respectively. The sequence of the motif is shown in lower panel.

\section{4-3-3 proteins}

The general mechanism of 14-3-3 protein action can be classified into three categories: 1) direct structural change of the bound partner, if the bound partner is an enzyme, this can affect its catalytic activity; 2) physical occlusion of sequence-specific or structural features of the target protein; and 3) stabilization of protein-protein interactions within multiprotein complexes (reviewed in (Aitken 1996, Fu et al. 2000, Tzivion and Avruch 2002, Bridges and Moorhead 2005, Obsil and Obsilova 2011)). Only few high-resolution crystal structures of 14-3-3 protein complexes have been reported until now. The first was the structure of the complex between 14-3-3 $\zeta$ and serotonin N-acetyltransferase (AANAT) (Obsil et al. 2001, Klein et al. 2003). Susbequently, structures of the 14-3-3:C-terminal part of the plasma membrane $\mathrm{H}^{+}$-ATPase complex and the ternary complex of rice 14-3-3:florigen Hd3a:FD1 transcription factor peptide were reported (Ottmann et al. 2007, Taoka et al. 2011). Recently, the structure of two other 14-3-3 protein complexes with full-length binding partners were solved: 14-3-3:heat shock protein beta- 6 (HSPB6) and 14-3-3:pNth1 (Alblova et al. 2017, Sluchanko et al. 2017a). Additional structural information was collected using low-resolution approaches, including studies on 14-3-3 complexes with transcription factor FOXO4 (Obsilova et al. 2005, Silhan et al. 2009), on the regulatory domain of human tyrosine hydroxylase (Obsilova et al. 2008), on the regulator of G-protein signalization 3 RGS3 (Rezabkova et al. 2010, Rezabkova et al. 2011), on protein kinases ASK1 and CaMKK2 (Kosek et al. 2014, Petrvalska et al. 2016, Psenakova et al. 2018), on Chibby (Killoran et al. 2015), on steroidogenic acute regulatory protein STARD1 (Sluchanko et al. 2017b) and on caspase-2 (Kalabova et al. 2017). The comparison of 14-3-3 protein structures in the absence and presence of ligands showed no significant structural changes in the 14-3-3 protein. This structural rigidity is caused by extensive hydrophobic interactions among $\alpha$-helices of 14-3-3 protein. This enables 14-3-3 proteins to function as stable rigid platform on which the conformation of their binding partners can be shaped (Yaffe 2002).

14-3-3 protein-dependent activation of Nth1 is a bona fide example of mode 1 regulation (direct structural change of bound partners) and resembles 14-3-3 protein-dependent AANAT activation (Obsil et al. 2001, Alblova et al. 2017). In both cases, 14-3-3 protein enhances the catalytic activity of the bound enzyme by inducing structural changes in the close proximity of the active site. These structures also revealed that interactions between 14-3-3 and its ligand could extend beyond those involving phosphorylated motifs and the ligand-binding groove. The involvement of less conserved regions in these contacts may explain the observed isoform-binding specificity among 14-3-3 isoforms and their ligands.

14-3-3 proteins usually recognize one of three types of specific phosphoserine $(\mathrm{pS})$ or phosphotreonine (pT) motifs, namely type I: $\mathrm{R}[\mathrm{S} / \Phi][+] \mathrm{pSXP}$, type II:RX $[S / \Phi][+] p S X P$ and type III:pS-X1-2-COOH, where $\Phi$ is an aromatic residue, + is a basic residue and $X$ can be any amino acid residue, except cysteine (Rittinger 
et al. 1999, Yaffe et al. 1997, Ganguly et al. 2005). However, these motifs vary widely because the number of 14-3-3 protein-binding partners is still increasing, and they may contain phosphorylated, unphosphorylated or even glycosylated motifs, which differ from the optimal motifs (Johnson et al. 2010, Masters et al. 1999, Toleman et al. 2018).

\section{Structural basis of $\mathrm{Ca}^{2+}$ and 14-3-3- dependent Nth1 activation}

The Nth1-CaBD is placed within the 14-3-3 central channel bordering both phosphorylated motifs and interacting with 14-3-3 helices H1, H3 and H9 and with the loop between $\mathrm{H} 1$ and $\mathrm{H} 2$ (Fig. 4A)(Alblova et al. 2017). Nth1-CaBD consists of three $\alpha$-helices and two antiparallel $\beta$-sheets, and the EF-hand-like is located between $\alpha 3$ and $\beta 2$ and is responsible for the $\mathrm{Ca}^{2+}$ coordination (Fig. 3). The structure of the catalytic domain of the 14-3-3-bound full-length pNth1 $1_{1-751}$ (Fig. 4A in salmon) is very similar to that of the isolated catalytic domain Nth1 $153-751$, except for the "lid loop" located between helices $\alpha 28$ and $\alpha 29$. In complexed pNth1 $1_{1-751}$, this "lid loop" covers the active site of pNth1, as shown in the Tre37A structure (Fig. 2 in red). However, in the isolated catalytic domain Nth1 $1_{153-751}$, the "lid loop" is disordered, likely due to its high flexibility (Fig. 2 in green). Although the Tre37A "lid loop" is
A

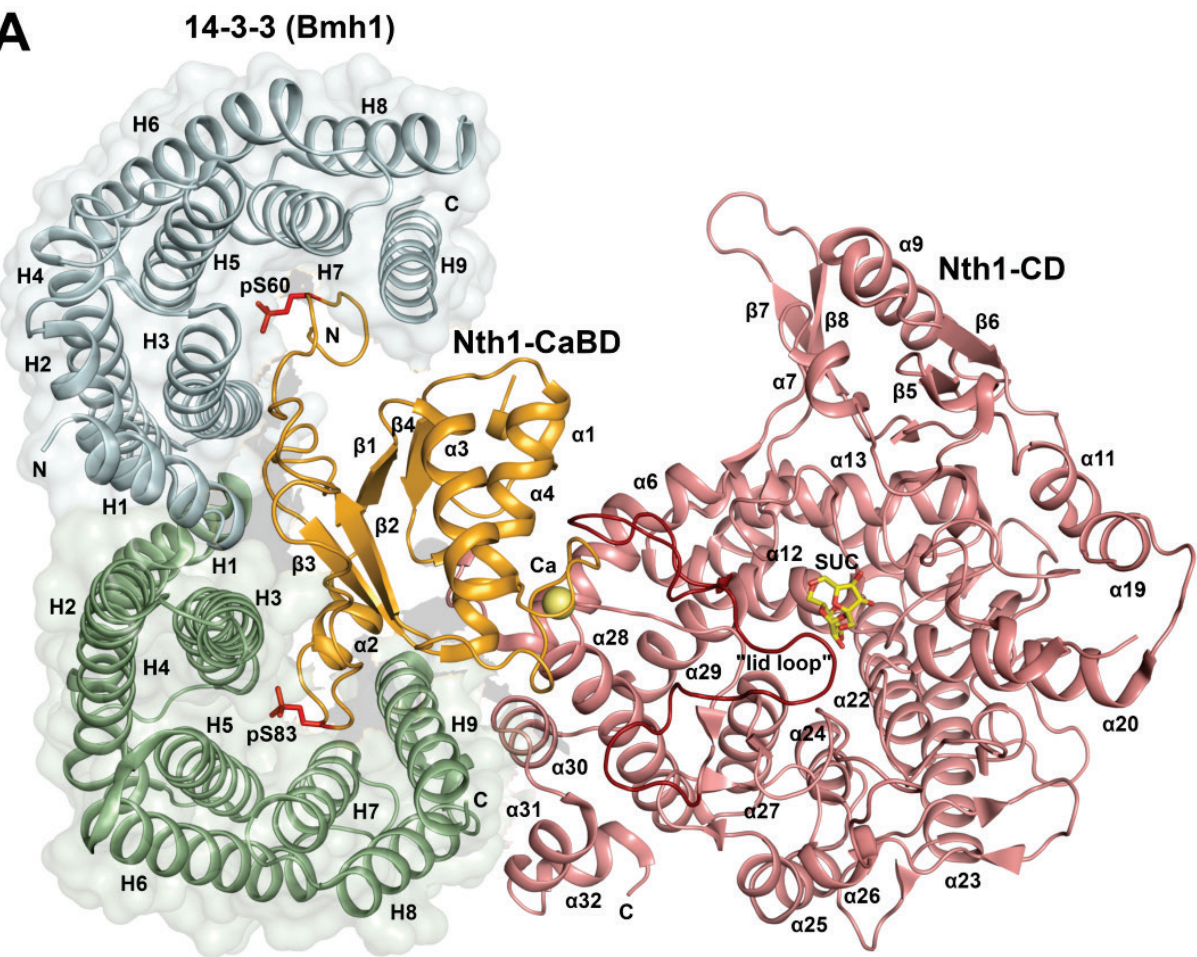

Fig. 4. Structure of the pNth $1_{1-751}$ : 14-3-3 complex. (A) pNth1 $1_{1-751}$ : yeast 14-3-3 (Bmh1) crystal structure (PDB: $5 \mathrm{~N} 6 \mathrm{~N}$ ). The N-terminal extensions of pNth $1_{1-751}$ and the Ca-binding domain (Nth1CaBD) are shown in orange. The catalytic domain of Nth1 (Nth1CD) is shown in salmon. 14-3-3 protomers are shown in cyan and green. The C-terminal portion of Nth1 "lid loop" and phosphorylated serines 60 and 83 are highlighted in red. The $\mathrm{Ca}^{2+}$ ion within the EF-hand-like motif and sucrose (SUC) in the Nth1 active center are in yellow. (B) Close-up view of the "lid loop" interactions with the EF-hand-like motif of Nth1-CaBD and the Nth1-CD regions surrounding the active site. The Nth1 "lid loop" residues are labeled in purple, the Nth1CaBD residues are labeled in orange and Nth1-CD residues in salmon (Alblova et al. 2017).

B

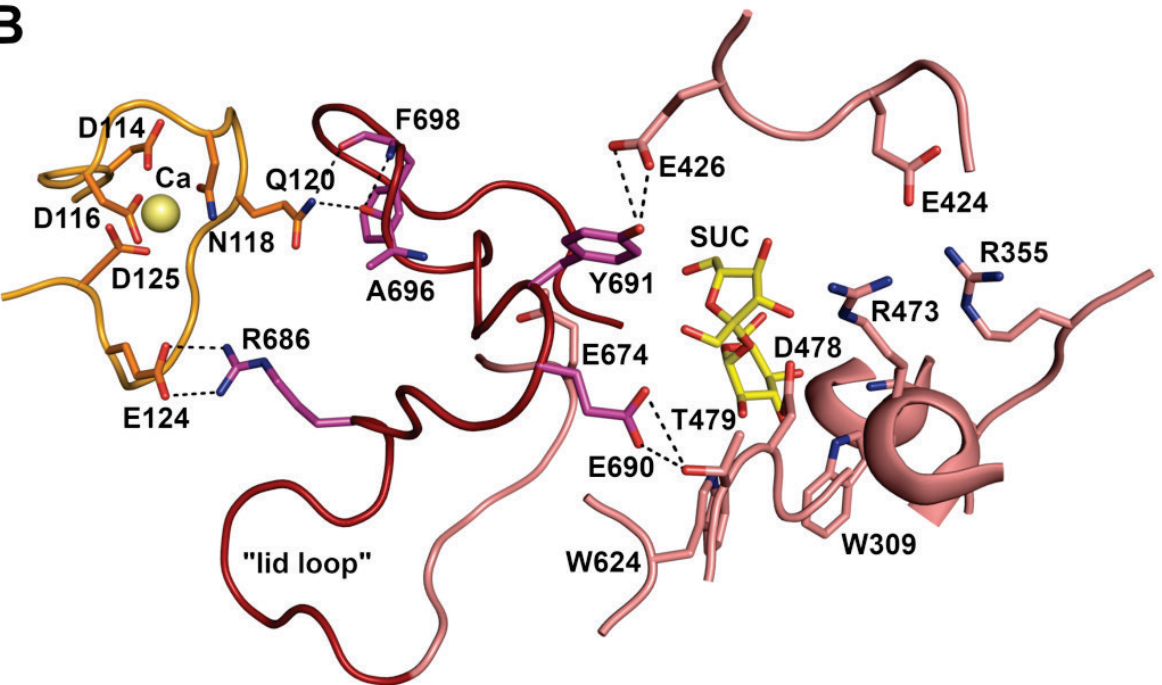


stabilized by contacts with bordering regions, the "lid loop" of complexed pNth1 is structured as a result of extensive interactions with the EF-hand-like motif (Fig. 4B). This motif is an integral part of Nth1-CaBD, which is held in the proper orientation with the respect to Nth1-CD by the 14-3-3 protein. Therefore, the "lid loop" of yeast Nth1 is stabilized by the proper orientation of Nth1-CaBD and Nth1-CD by the scaffolding protein 14-3-3. The tip of the stabilized lid loop then provides residues E690 and Y691 crucial for catalysis (Gibson et al. 2007, Alblova et al. 2017). Calcium-binding stabilizes the interface between Nth1-CaBD and Nth1-CD and thus potentiates 14-3-3-mediated pNth1 activation. This mechanism is consistent with the previously published results of the hydrogen-deuterium exchange coupled to mass spectrometry (HDX-MS) analysis, which suggested that both Nth1-CaBD (Fig. 5 in red) and several regions within Nth1-CD surrounding the active site and the "lid loop" (Fig. 5 in blue and "lid loop" in green) undergo significant structural changes in the presence of $\mathrm{Ca}^{2+}$ and/or 14-3-3 protein (Kopecka et al. 2014, Macakova et al. 2013). Moreover, the sequence alignment of $S$. cerevisiae neutral trehalases Nth1 and Nth2 and neutral trehalases from other yeast species such as Candida albicans, Kluyveromyces lactis or Schizosaccharomyces pombe revealed that all yeast neutral trehalases possess the combination of PKA phosphorylation sites, $\mathrm{Ca}^{2+}$-binding and catalytic domains and distinct "lid loop" sequences indicating that the regulation in 14-3-3 dependent manner is a general feature for all yeast neutral trehalases (Alblova et al. 2017).

\section{4-3-3 binding induces Nth1 disorder-to order-transition}

Bioinformatic studies revealed that $90 \%$ of 14-3-3 protein binding partners are partly or totally disordered and that their 14-3-3 binding motifs are mostly located within intrinsically disordered regions. These regions are most often present at their $\mathrm{N}$ - or C-termini or bordering their functional domains (Bustos and Iglesias 2006, Johnson et al. 2010). The plasticity and flexibility of disordered regions provide several functional advantages to the signaling proteins, such as binding to different binding partners and/or the sensitive control of their binding affinities (Dyson and Wright 2002, Wright and Dyson 2009). The next reason for the participation of disordered regions in binding interactions can be the improved ability to search for suitable binding partners,

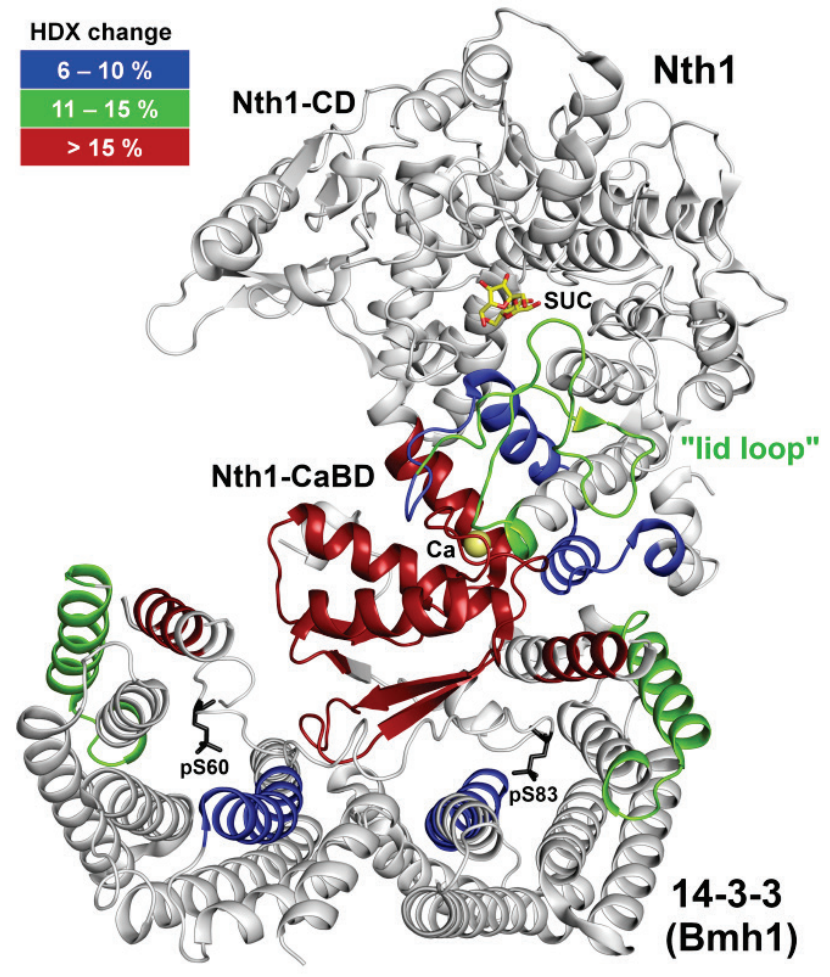

Fig. 5. HDX-MS reveals conformational changes of pNth $1_{1-751}$ or 14-3-3 protein (Bmh1). The regions that show slower deuterium exchange kinetics upon pNth1:14-3-3 complex formation mapped onto the crystal structure of pNth1 $1_{1-751}: 14-3-3$ complex (PDB: $5 \mathrm{~N} 6 \mathrm{~N}$, shown in grey). Regions with 6-10 \% HDX change after 10 min of deuteration are shown in blue, $11-15 \%$ in green and higher than $15 \%$ in red (Macakova et al. 2013, Kopecka et al. 2014, Alblova et al. 2017).

in contrast to compact, perfectly folded proteins with limited conformational flexibility (Shoemaker et al. 2000). Thus, the 14-3-3 protein binding to disordered segments can lead to significant disorder-to-order transitions in their binding partners. HDX-MS data suggested that this is also the case of pNth1, especially Nth1-CaBD, where a dramatic decrease in deuteration kinetics was observed upon the complex formation (slower HDX is consistent with a more structured state). 14-3-3-mediated pNth1 disorder-to-order transition was also shown by small-angle X-ray scattering (SAXS) measurements (Kopecka et al. 2014). The dimensionless Kratky plots, calculated from the scattering data of Nth1, yeast 14-3-3 (Bmh1) and their complex, suggest that 14-3-3 alone and the pNth1:14-3-3 complex exhibit substantially lower conformational flexibility than Nth1 alone. The scattering data of compact globular proteins in this plot show a maximum value of 1.104 at $\mathrm{sRg} \sim 1.73$ (showed by grey lines in Fig. 6) (Receveur-Brechot and Durand 2012). 


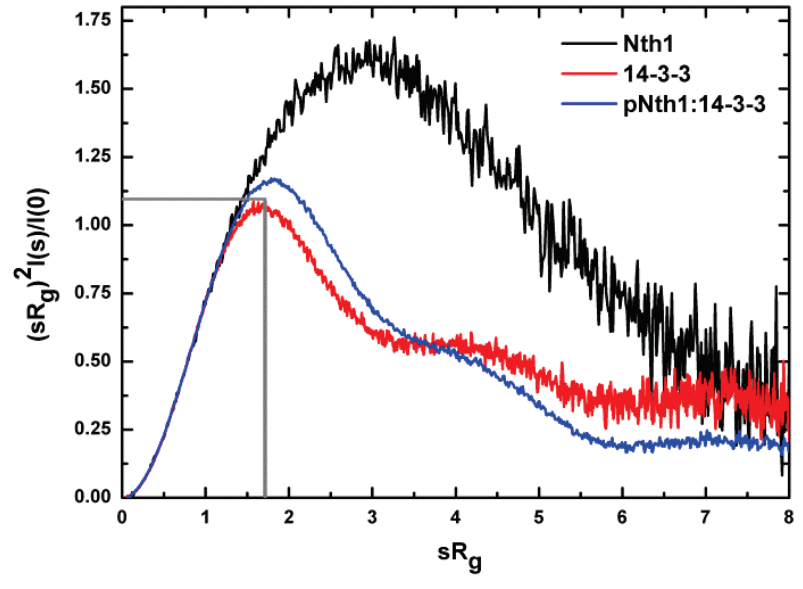

Fig. 6. Dimensionless Kratky plots. SAXS data collected at the corresponding protein concentrations are shown in black for Nth1 $(1.8 \mathrm{mg} / \mathrm{ml})$, in red for yeast $14-3-3(B m h 1)(8.6 \mathrm{mg} / \mathrm{ml})$ and in blue for the pNth1:14-3-3 complex mixed at $1: 2$ molar stoichiometry $(15 \mathrm{mg} / \mathrm{ml})$. Grey lines mark the maximum at a value of 1.104 for $s R_{g}=1.732$, a typical attribute for the scattering data of compact globular proteins (Kopecka et al. 2014).

\section{Conclusions}

14-3-3 proteins serve as "readers" of phosphorylated motifs, and by these interactions they regulate the function of a number of biologically important signaling processes. Yeast neutral trehalases, crucial enzymes for yeast metabolism, differ from those of other prokaryotic and higher eukaryotic organisms because they have an N-terminal extension, with two 14-3-3 binding motifs and with an Nth1-CaBD, and a distinct "lid loop" sequence within Nth1-CD. 14-3-3 protein binding modulates Nth1 activity by enabling the proper three-dimensional configuration of Nth1-CD and $\mathrm{CaBD}$ domains relative to each other, thus stabilizing the flexible "lid loop" over the active site and providing residues important for catalysis.

\section{Conflict of Interest}

There is no conflict of interest.

\section{Acknowledgements}

This study was funded by the Czech Science Foundation (V.O., grant number 17-00726S), the Czech Academy of Sciences (RVO:67985823 of the Institute of Physiology), project BIOCEV (CZ.1.05/1.1.00.02.0109) and MEYS CR (LM2015043 CIISB, Biocev, Crystallisation, Diffraction, Biophysical methods, Structural Mass Spectrometry).

We thank Dr. Carlos V. Melo for proofreading the article.

\section{References}

AITKEN A: 14-3-3 and its possible role in co-ordinating multiple signalling pathways. Trends Cell Biol 6: 341-347, 1996.

ALBLOVA M, SMIDOVA A, DOCEKAL V, VESELY J, HERMAN P, OBSILOVA V, OBSIL T: Molecular basis of the 14-3-3 protein-dependent activation of yeast neutral trehalase Nth1. Proceedings of the National Academy of Sciences of the United States of America 114: E9811-E9820, 2017.

ALESHIN AE, HOFFMAN C, FIRSOV LM, HONZATKO RB: Refined crystal structures of glucoamylase from Aspergillus awamori var. X100. J Mol Biol 238: 575-591, 1994.

AMARAL FC, VAN DIJCK P, NICOLI JR, THEVELEIN JM: Molecular cloning of the neutral trehalase gene from Kluyveromyces lactis and the distinction between neutral and acid trehalases. Arch Microbiol 167: 202-208, 1997.

APP H, HOLZER H: Purification and characterization of neutral trehalase from the yeast ABYS1 mutant. $J$ Biol Chem 264: 17583-17588, 1989.

BECKER A, SCHLODER P, STEELE JE, WEGENER G: The regulation of trehalose metabolism in insects. Experientia 52: 433-439, 1996.

BOCK K, DEFAYE J, DRIGUEZ H, BAR-GUILLOUX E: Conformations in solution of alpha,alpha-trehalose, alphaD-glucopyranosyl alpha-D-mannopyranoside, and their 1-thioglycosyl analogs, and a tentative correlation of their behaviour with respect to the enzyme trehalase. Eur J Biochem 131: 595-600, 1983.

BRIDGES D, MOORHEAD GB: 14-3-3 proteins: a number of functions for a numbered protein. Sci STKE 2005: re10, 2005.

BUSTOS DM, IGLESIAS AA: Intrinsic disorder is a key characteristic in partners that bind 14-3-3 proteins. Proteins 63: 35-42, 2006.

CROWE JH, CROWE LM, CHAPMAN D: Preservation of membranes in anhydrobiotic organisms: the role of trehalose. Science 223: 701-703, 1984. 
CROWE JH, HOEKSTRA FA, CROWE LM: Anhydrobiosis. Annu Rev Physiol 54: 579-599, 1992.

D'ENFERT C, BONINI BM, ZAPELLA PD, FONTAINE T, DA SILVA AM, TERENZI HF: Neutral trehalases catalyse intracellular trehalose breakdown in the filamentous fungi Aspergillus nidulans and Neurospora crassa. Mol Microbiol 32: 471-483, 1999.

DE MESQUITA JF, PANEK AD, DE ARAUJO PS: In silico and in vivo analysis reveal a novel gene in Saccharomyces cerevisiae trehalose metabolism. BMC Genomics 4: 45, 2003.

DE VIRGILIO C, HOTTIGER T, DOMINGUEZ J, BOLLER T, WIEMKEN A: The role of trehalose synthesis for the acquisition of thermotolerance in yeast. I. Genetic evidence that trehalose is a thermoprotectant. Eur J Biochem 219: 179-186, 1994.

DYSON HJ, WRIGHT PE: Coupling of folding and binding for unstructured proteins. Curr Opin Struct Biol 12: 54-60, 2002.

ECK R, BERGMANN C, ZIEGELBAUER K, SCHONFELD W, KUNKEL W: A neutral trehalase gene from Candida albicans: molecular cloning, characterization and disruption. Microbiology 143 (Pt 12): 3747-3756, 1997.

EGLOFF MP, UPPENBERG J, HAALCK L, VAN TILBEURGH H: Crystal structure of maltose phosphorylase from Lactobacillus brevis: unexpected evolutionary relationship with glucoamylases. Structure 9: 689-697, 2001.

ELBEIN AD: The metabolism of alpha,alpha-trehalose. Adv Carbohydr Chem Biochem 30: 227-256, 1974.

ELBEIN AD, PAN YT, PASTUSZAK I, CARROLL D: New insights on trehalose: a multifunctional molecule. Glycobiology 13: 17R-27R, 2003.

EWALD JC, KUEHNE A, ZAMBONI N, SKOTHEIM JM: The Yeast Cyclin-Dependent Kinase Routes Carbon Fluxes to Fuel Cell Cycle Progression. Molecular Cell 62: 532-545, 2016.

FISCHER E: Über den Einfluß der Configuration auf die Wirkung der Enzyme. III. (in German) Ber Dtsch Chem Ges 28: 1429-1438, 1895.

FOSTER AJ, JENKINSON JM, TALBOT NJ: Trehalose synthesis and metabolism are required at different stages of plant infection by Magnaporthe grisea. The EMBO journal 22: 225-235, 2003.

FRANCO A, SOTO T, VICENTE-SOLER J, PAREDES V, MADRID M, GACTO M, CANSADO J: A role for calcium in the regulation of neutral trehalase activity in the fission yeast Schizosaccharomyces pombe. Biochem J 376: 209-217, 2003.

FRANCOIS J, PARROU JL: Reserve carbohydrates metabolism in the yeast Saccharomyces cerevisiae. FEMS Microbiol Rev 25: 125-145, 2001.

FU H, SUBRAMANIAN RR, MASTERS SC: 14-3-3 proteins: structure, function, and regulation. Annu Rev Pharmacol Toxicol 40: 617-647, 2000.

GANGULY S, WELlER JL, HO A, CHEMINEAU P, MALPAUX B, KLEIN DC: Melatonin synthesis: 14-3-3-dependent activation and inhibition of arylalkylamine N-acetyltransferase mediated by phosphoserine205. Proc Natl Acad Sci US A 102: 1222-1227, 2005.

GIBSON RP, GLOSTER TM, ROBERTS S, WARREN RA, STORCH DE GRACIA I, GARCIA A, CHIARA JL, DAVIES GJ: Molecular basis for trehalase inhibition revealed by the structure of trehalase in complex with potent inhibitors. Angew Chem Int Ed Engl 46: 4115-4119, 2007.

GUILLOU V, PLOURDE-OWOBI L, PARROU JL, GOMA G, FRANCOIS J: Role of reserve carbohydrates in the growth dynamics of Saccharomyces cerevisiae. FEMS Yeast Res 4: 773-787, 2004.

HIDAKA M, KITAOKA M, HAYASHI K, WAKAGI T, SHOUN H, FUSHINOBU S: Crystallization and preliminary $\mathrm{X}$-ray analysis of cellobiose phosphorylase from Cellvibrio gilvus. Acta Crystallogr D Biol Crystallogr 60: 1877-1878, 2004.

HOLT LJ, TUCH BB, VILLEN J, JOHNSON AD, GYGI SP, MORGAN DO: Global analysis of Cdk1 substrate phosphorylation sites provides insights into evolution. Science 325: 1682-1686, 2009.

HOTTIGER T, BOLLER T, WIEMKEN A: Rapid changes of heat and desiccation tolerance correlated with changes of trehalose content in Saccharomyces cerevisiae cells subjected to temperature shifts. Febs Letters 220: 113-115, 1987.

HOTTIGER T, DE VIRGILIO C, HALL MN, BOLLER T, WIEMKEN A: The role of trehalose synthesis for the acquisition of thermotolerance in yeast. II. Physiological concentrations of trehalose increase the thermal stability of proteins in vitro. Eur J Biochem 219: 187-193, 1994. 
JOHNSON C, CROWTHER S, STAFFORD MJ, CAMPBELL DG, TOTH R, MACKINTOSH C: Bioinformatic and experimental survey of 14-3-3-binding sites. Biochem J 427: 69-78, 2010.

KALABOVA D, SMIDOVA A, PETRVALSKA O, ALBLOVA M, KOSEK D, MAN P, OBSIL T, OBSILOVA V: Human procaspase-2 phosphorylation at both S139 and S164 is required for 14-3-3 binding. Biochem Biophys Res Commun 493: 940-945, 2017.

KILLORAN RC, FAN J, YANG D, SHILTON BH, CHOY WY: Structural Analysis of the 14-3-3zeta/Chibby Interaction Involved in Wnt/beta-Catenin Signaling. PLoS One 10: e0123934, 2015.

KLEIN DC, GANGULY S, COON SL, SHI Q, GAILDRAT P, MORIN F, WELLER JL, OBSIL T, HICKMAN A, DYDA F: 14-3-3 proteins in pineal photoneuroendocrine transduction: how many roles? $J$ Neuroendocrinol 15: 370-377, 2003.

KOCH EM, KOCH FC: The Presence of Trehalose in Yeast. Science 61: 570-572, 1925.

KOPECKA M, KOSEK D, KUKACKA Z, REZABKOVA L, MAN P, NOVAK P, OBSIL T, OBSILOVA V: Role of the EF-hand-like motif in the 14-3-3 protein-mediated activation of yeast neutral trehalase Nth1. J Biol Chem 289: 13948-13961, 2014.

KOPP M, MULLER H, HOLZER H: Molecular analysis of the neutral trehalase gene from Saccharomyces cerevisiae. J Biol Chem 268: 4766-4774, 1993.

KOPP M, NWAKA S, HOLZER H: Corrected sequence of the yeast neutral trehalase-encoding gene (NTH1): biological implications. Gene 150: 403-404, 1994.

KOSEK D, KYLAROVA S, PSENAKOVA K, REZABKOVA L, HERMAN P, VECER J, OBSILOVA V, OBSIL T: Biophysical and structural characterization of the thioredoxin-binding domain of protein kinase ASK1 and its interaction with reduced thioredoxin. J Biol Chem 289: 24463-24474, 2014.

KUENZI MT, FIECHTER A: Changes in carbohydrate composition and trehalase-activity during the budding cycle of Saccharomyces cerevisiae. Arch Mikrobiol 64: 396-407, 1969.

LILLIE SH, PRINGLE JR: Reserve carbohydrate metabolism in Saccharomyces cerevisiae: responses to nutrient limitation. J Bacteriol 143: 1384-1394, 1980.

LIU D, BIENKOWSKA J, PETOSA C, COLLIER RJ, FU H, LIDDINGTON R: Crystal structure of the zeta isoform of the 14-3-3 protein. Nature 376: 191-194, 1995.

LIU H, RODGERS ND, JIAO X, KILEDJIAN M: The scavenger mRNA decapping enzyme DcpS is a member of the HIT family of pyrophosphatases. Embo $J$ 21: 4699-4708, 2002.

LONDESBOROUGH J, VARIMO K: Characterization of two trehalases in baker's yeast. Biochem J 219: 511-518, 1984.

MACAKOVA E, KOPECKA M, KUKACKA Z, VEISOVA D, NOVAK P, MAN P, OBSIL T, OBSILOVA V: Structural basis of the 14-3-3 protein-dependent activation of yeast neutral trehalase Nth1. Biochim Biophys Acta 1830: 4491-4499, 2013.

MASTERS SC, PEDERSON KJ, ZHANG L, BARBIERI JT, FU H: Interaction of 14-3-3 with a nonphosphorylated protein ligand, exoenzyme $S$ of Pseudomonas aeruginosa. Biochemistry 38: 5216-5221, 1999.

MULLER D, EXLER S, AGUILERA-VAZQUEZ L, GUERRERO-MARTIN E, REUSS M: Cyclic AMP mediates the cell cycle dynamics of energy metabolism in Saccharomyces cerevisiae. Yeast 20: 351-367, 2003.

NWAKA S, KOPP M, HOLZER H: Expression and function of the trehalase genes NTH1 and YBR0106 in Saccharomyces cerevisiae. J Biol Chem 270: 10193-10198, 1995.

NWAKA S, MECHLER B, VON AHSEN O, HOLZER H: The heat shock factor and mitochondrial Hsp70 are necessary for survival of heat shock in Saccharomyces cerevisiae. FEBS Lett 399: 259-263, 1996.

NWAKA S, HOLZER H: Molecular biology of trehalose and the trehalases in the yeast Saccharomyces cerevisiae. Prog Nucleic Acid Res Mol Biol 58: 197-237, 1998.

OBSIL T, GHIRLANDO R, KLEIN DC, GANGULY S, DYDA F: Crystal structure of the 14-3-3zeta:serotonin N-acetyltransferase complex. a role for scaffolding in enzyme regulation. Cell 105: 257-267, 2001.

OBSIL T, OBSILOVA V: Structural basis of 14-3-3 protein functions. Semin Cell Dev Biol 22: 663-672, 2011.

OBSILOVA V, VECER J, HERMAN P, PABIANOVA A, SULC M, TEISINGER J, BOURA E, OBSIL T: 14-3-3 Protein interacts with nuclear localization sequence of forkhead transcription factor FoxO4. Biochemistry 44: 11608-11617, 2005. 
OBSILOVA V, NEDBALKOVA E, SILHAN J, BOURA E, HERMAN P, VECER J, SULC M, TEISINGER J, DYDA F, OBSIL T: The 14-3-3 protein affects the conformation of the regulatory domain of human tyrosine hydroxylase. Biochemistry 47: 1768-1777, 2008.

ORTIZ CH, MAIA JC, TENAN MN, BRAZ-PADRAO GR, MATTOON JR, PANEK AD: Regulation of yeast trehalase by a monocyclic, cyclic AMP-dependent phosphorylation-dephosphorylation cascade system. J Bacteriol 153: 644-651, 1983.

OTTMANN C, MARCO S, JASPERT N, MARCON C, SCHAUER N, WEYAND M, VANDERMEEREN C, DUBY G, BOUTRY M, WITTINGHOFER A, RIGAUD JL, OECKING C: Structure of a 14-3-3 coordinated hexamer of the plant plasma membrane $\mathrm{H}+$-ATPase by combining X-ray crystallography and electron cryomicroscopy. Mol Cell 25: 427-440, 2007.

PANEK AC, DE ARAUJO PS, MOURA NETO V, PANEK AD: Regulation of the trehalose-6-phosphate synthase complex in Saccharomyces. I. Interconversion of forms by phosphorylation. Curr Genet 11: 459-465, 1987.

PANNI S, LANDGRAF C, VOLKMER-ENGERT R, CESARENI G, CASTAGNOLI L: Role of 14-3-3 proteins in the regulation of neutral trehalase in the yeast Saccharomyces cerevisiae. FEMS Yeast Res 8: 53-63, 2008.

PETRVALSKA O, KOSEK D, KUKACKA Z, TOSNER Z, MAN P, VECER J, HERMAN P, OBSILOVA V, OBSIL T: Structural Insight into the 14-3-3 Protein-dependent Inhibition of Protein Kinase ASK1 (Apoptosis Signalregulating kinase 1). J Biol Chem 291: 20753-20765, 2016.

PETZOLD EW, HIMMELREICH U, MYLONAKIS E, RUDE T, TOFFALETTI D, COX GM, MILLER JL, PERFECT JR: Characterization and regulation of the trehalose synthesis pathway and its importance in the pathogenicity of Cryptococcus neoformans. Infect Immun 74: 5877-5887, 2006.

PSENAKOVA K, PETRVALSKA O, KYLAROVA S, LENTINI SANTO D, KALABOVA D, HERMAN P, OBSILOVA V, OBSIL T: 14-3-3 protein directly interacts with the kinase domain of calcium/calmodulindependent protein kinase kinase (CaMKK2). Biochim Biophys Acta 1862: 1612-1625, 2018.

RECEVEUR-BRECHOT V, DURAND D: How random are intrinsically disordered proteins? A small angle scattering perspective. Curr Protein Pept Sci 13: 55-75, 2012.

REZABKOVA L, BOURA E, HERMAN P, VECER J, BOUROVA L, SULC M, SVOBODA P, OBSILOVA V, OBSIL T: 14-3-3 protein interacts with and affects the structure of RGS domain of regulator of $\mathrm{G}$ protein signaling 3 (RGS3). $J$ Struct Biol 170: 451-461, 2010.

REZABKOVA L, MAN P, NOVAK P, HERMAN P, VECER J, OBSILOVA V, OBSIL T: Structural basis for the 14-3-3 protein-dependent inhibition of the regulator of G protein signaling 3 (RGS3) function. $J$ Biol Chem 286: 43527-43536, 2011.

RITTINGER K, BUDMAN J, XU J, VOLINIA S, CANTLEY LC, SMERDON SJ, GAMBLIN SJ, YAFFE MB: Structural analysis of 14-3-3 phosphopeptide complexes identifies a dual role for the nuclear export signal of 14-3-3 in ligand binding. Mol Cell 4: 153-166, 1999.

ROUSSEAU P, HALVORSON HO, BULLA LA, JR, ST JULIAN G: Germination and outgrowth of single spores of Saccharomyces cerevisiae viewed by scanning electron and phase-contrast microscopy. J Bacteriol 109: 1232-1238, 1972.

SHOEMAKER BA, PORTMAN JJ, WOLYNES PG: Speeding molecular recognition by using the folding funnel: the fly-casting mechanism. Proc Natl Acad Sci U S A 97: 8868-8873, 2000.

SCHEPERS W, VAN ZEEBROECK G, PINKSE M, VERHAERT P, THEVELEIN JM: In vivo phosphorylation of Ser21 and Ser83 during nutrient-induced activation of the yeast protein kinase A (PKA) target trehalase. J Biol Chem 287: 44130-44142, 2012.

SILHAN J, VACHA P, STRNADOVA P, VECER J, HERMAN P, SULC M, TEISINGER J, OBSILOVA V, OBSIL T: 14-3-3 protein masks the DNA binding interface of forkhead transcription factor FOXO4. J Biol Chem 284: 19349-19360, 2009.

SILLJE HH, PAALMAN JW, TER SCHURE EG, OLSTHOORN SQ, VERKLEIJ AJ, BOONSTRA J, VERRIPS CT: Function of trehalose and glycogen in cell cycle progression and cell viability in Saccharomyces cerevisiae. J Bacteriol 181: 396-400, 1999.

SINGER MA, LINDQUIST S: Multiple effects of trehalose on protein folding in vitro and in vivo. Mol Cell 1: 639-648, 1998. 
SLUCHANKO NN, BEELEN S, KULIKOVA AA, WEEKS SD, ANTSON AA, GUSEV NB, STRELKOV SV: Structural Basis for the Interaction of a Human Small Heat Shock Protein with the 14-3-3 Universal Signaling Regulator. Structure 25: 305-316, $2017 \mathrm{a}$.

SLUCHANKO NN, TUGAEVA KV, MAKSIMOV EG: Solution structure of human steroidogenic acute regulatory protein STARD1 studied by small-angle X-ray scattering. Biochem Biophys Res Commun 489: 445-450, $2017 \mathrm{~b}$.

SOTO T, FERNANDEZ J, DOMINGUEZ A, VICENTE-SOLER J, CANSADO J, GACTO M: Analysis of the ntp1+ gene, encoding neutral trehalase in the fission yeast Schizosaccharomyces pombe. Biochim Biophys Acta 1443: 225-229, 1998.

SOTO T, FERNANDEZ J, VICENTE-SOLER J, CANSADO J, GACTO M: Accumulation of trehalose by overexpression of tps1, coding for trehalose-6-phosphate synthase, causes increased resistance to multiple stresses in the fission yeast schizosaccharomyces pombe. Appl Environ Microbiol 65: 2020-2024, 1999.

TAOKA K, OHKI I, TSUJI H, FURUITA K, HAYASHI K, YANASE T, YAMAGUCHI M, NAKASHIMA C, PURWESTRI YA, TAMAKI S, OGAKI Y, SHIMADA C, NAKAGAWA A, KOJIMA C, SHIMAMOTO K: 14-3-3 proteins act as intracellular receptors for rice Hd3a florigen. Nature 476: 332-335, 2011.

THEVELEIN JM, DEN HOLLANDER JA, SHULMAN RG: Changes in the activity and properties of trehalase during early germination of yeast ascospores: correlation with trehalose breakdown as studied by in vivo 13C NMR. Proc Natl Acad Sci US A 79: 3503-3507, 1982.

THEVELEIN JM, JONES KA: Reversibility characteristics of glucose-induced trehalase activation associated with the breaking of dormancy in yeast ascospores. Eur J Biochem 136: 583-587, 1983.

THEVELEIN JM: Activation of trehalase by membrane-depolarizing agents in yeast vegetative cells and ascospores. J Bacteriol 158: 337-339, 1984a.

THEVELEIN JM: Regulation of trehalose mobilization in fungi. Microbiol Rev 48: 42-59, $1984 \mathrm{~b}$.

TOLEMAN CA, SCHUMACHER MA, YU SH, ZENG W, COX NJ, SMITH TJ, SODERBLOM EJ, WANDS AM, KOHLER JJ, BOYCE M: Structural basis of O-GlcNAc recognition by mammalian 14-3-3 proteins. Proc Natl Acad Sci US A, 2018.

TZIVION G, AVRUCH J: 14-3-3 proteins: active cofactors in cellular regulation by serine/threonine phosphorylation. J Biol Chem 277: 3061-3064, 2002.

UBERSAX JA, WOODBURY EL, QUANG PN, PARAZ M, BLETHROW JD, SHAH K, SHOKAT KM, MORGAN DO: Targets of the cyclin-dependent kinase Cdk1. Nature 425: 859-864, 2003.

UNO I, MATSUMOTO K, ADACHI K, ISHIKAWA T: Genetic and biochemical evidence that trehalase is a substrate of cAMP-dependent protein kinase in yeast. J Biol Chem 258: 10867-10872, 1983.

VAN ASSCHE JA, CARLIER AR, DEKEERSMAEKER HI: Trehalase activity in dormant and activated spores of Phycomyces blakesleeanus. Planta 103: 327-333, 1972.

VAN DER PLAAT JB: Cyclic 3',5'-adenosine monophosphate stimulates trehalose degradation in baker's yeast. Biochem Biophys Res Commun 56: 580-587, 1974.

VAN DIJCK P, DE ROP L, SZLUFCIK K, VAN AEL E, THEVELEIN JM: Disruption of the Candida albicans TPS2 gene encoding trehalose-6-phosphate phosphatase decreases infectivity without affecting hypha formation. Infect Immun 70: 1772-1782, 2002.

VAN HEUSDEN GP, YDE STEENSMA H: Yeast 14-3-3 proteins. Yeast 23: 159-171, 2006.

VAN HEUSDEN GP: 14-3-3 Proteins: insights from genome-wide studies in yeast. Genomics 94: 287-293, 2009.

VANDERCAMMEN A, FRANCOIS J, HERS HG: Characterization of trehalose-6-phosphate synthase and trehalose-6phosphate phosphatase of Saccharomyces cerevisiae. Eur J Biochem 182: 613-620, 1989.

VEISOVA D, MACAKOVA E, REZABKOVA L, SULC M, VACHA P, SYCHROVA H, OBSIL T, OBSILOVA V: Role of individual phosphorylation sites for the 14-3-3-protein-dependent activation of yeast neutral trehalase Nth1. Biochem J 443: 663-670, 2012.

WIEMKEN A: Trehalose in yeast, stress protectant rather than reserve carbohydrate. Antonie Van Leeuwenhoek 58: 209-217, 1990.

WRIGHT PE, DYSON HJ: Linking folding and binding. Curr Opin Struct Biol 19: 31-38, 2009. 
XIAO B, SMERDON SJ, JONES DH, DODSON GG, SONEJI Y, AITKEN A, GAMBLIN SJ: Structure of a 14-3-3 protein and implications for coordination of multiple signalling pathways. Nature 376: 188-191, 1995.

YAFFE MB, RITTINGER K, VOLINIA S, CARON PR, AITKEN A, LEFFERS H, GAMBLIN SJ, SMERDON SJ, CANTLEY LC: The structural basis for 14-3-3:phosphopeptide binding specificity. Cell 91: 961-971, 1997.

YAFFE MB: How do 14-3-3 proteins work?-- Gatekeeper phosphorylation and the molecular anvil hypothesis. FEBS Lett 513: 53-57, 2002.

ZAHRINGER H, BURGERT M, HOLZER H, NWAKA S: Neutral trehalase Nth1p of Saccharomyces cerevisiae encoded by the NTH1 gene is a multiple stress responsive protein. FEBS Lett 412: 615-620, 1997.

ZHAO G, CHEN Y, CAREY L, FUTCHER B: Cyclin-Dependent Kinase Co-Ordinates Carbohydrate Metabolism and Cell Cycle in S. cerevisiae. Mol Cell 62: 546-557, 2016. 